\title{
DIFFERENTIAL ROLES FOR DOPAMINE D1-LIKE AND D2-LIKE RECEPTORS IN LEARNING AND BEHAVIOR OF HONEYBEE AND OTHER INSECTS
}

\author{
RAZA, M. F. ${ }^{1,2}-$ SU, S. ${ }^{1 *}$ \\ ${ }^{1}$ College of Animal Sciences (College of Bee Science), Fujian Agriculture and Forestry \\ University, Fuzhou, China \\ ${ }^{2}$ College of Life Sciences, Fujian Agriculture and Forestry University, Fuzhou 35002, China \\ *Corresponding author \\ e-mail: susongkun@zju.edu.cn; phone: +86-136-6500-5782 \\ (Received $9^{\text {th }}$ Sep 2019; accepted $4^{\text {th }}$ Dec 2019)
}

\begin{abstract}
Biogenic amines and neuropeptides are important neurotransmitters and modulators in the peripheral and central nervous systems of several invertebrate species. Biogenic amines play essential roles in modulating physiological and behavioral processes as neuromodulators, neurotransmitters, and neurohormones. Biogenic amines such as octopamine, dopamine, tyramine, or even serotonin can act as slow neuromodulator or fast transmitters. In both invertebrates and vertebrates, dopamine found in the central nervous system. Dopamine receptors (D1-like family - D1, D5) and (D2-like family- D2, D3, D4) directly modulate and regulate other neurotransmitters, the release of cyclic adenosine monophosphate (cAMP), differentiation, and cell proliferation. Here, we highlighted the essential role of dopamine and dopamine receptors in the control of cognition, locomotion, attention, memory formation, and behavioral plasticity in the central nervous system (CNS). In CNS, D1-like and D2-like are the most abundant dopamine receptors. Dopamine receptors contribution in several aspects of motor function, cognition besides reinforcement/reward and complex behavior. Behavioral and mental diseases associated with major neurotransmission disruptions of dopamine as well as hyperactivity/attention-deficit disorder, schizophrenia, substance abuse, and Huntington's disease cause a major neuropsychological deficiency in attention, memory, and learning besides to other major symptoms.
\end{abstract}

Keywords: biogenic amines, honeybee, memory, receptors, olfactory learning

\section{Introduction}

In numerous social insects, such as bees and ants, biogenic amines perform decisive roles in the regulation of sociality. How biogenic amines (BA) and their receptors in ancestral, most of the solitary species have been chosen during the change to control different behaviors in complex social species are discussed by Kamhi et al. (2017). Biogenic amines are vital messenger elements in the central nervous system (CNS) and the peripheral area of invertebrates and vertebrates. Honeybee, A. mellifera, is outstandingly appropriated to reveal the biogenic amines functions in behavior, as long as it has wide-ranging behavioral capabilities, in this insect, there are a lot of biogenic amine receptors (Scheiner et al., 2006). Biogenic amines are involved in coordinating responses related to metabolic reactions, for instance, starvation. Whenever there exist starve $d$ rate-limiting enzyme tyrosine- $\beta$-hydroxylase mutant fruit flies, octopamine cannot be synthesized, having higher concentrations of glucose level in their hemolymph compared to controls, as revealed by Li et al. (2017). Damrau et al. (2018) investigated starvation or fat deposition resistance by using fruit flies defective in the expression of tyramine and octopamine receptors. Their tissue-specific RNAi experiments showed a very complicated interorgan transmission resulting in various 
metabolic phenotypes in tyramine and octopamine lacking fruit flies. Stocker et al. (2018) reported the comparison of the axon terminals of octopaminergic efferent ventral and dorsal median unpaired neurons in whether fruit flies or desert locusts throughout skeletal muscles, exposing numerous similarities. For both octopamine and tyramine, type 11 terminals are immunopositive and dissimilarity to the type I terminals that have visible synaptic blades, and they comprise of dense-core vesicles. They revealed that hunger modulates the neuromuscular-branched morphology in a time-based manner. In this mini-review, we discuss the role of dopamine (DA) receptors to regulate the behavior in honeybee and other insects and summarize the role of dopamine, types, physiology, and genes of dopamine receptors.

Moreover, the authors confirmed that the delivery of octopamine from axonal and dendritic type II terminals applies parallel to synaptic machinery to glutamate allow from excitatory motor neurons (type I terminals). Buckemüller et al. (2017) examined changes in glucose concentration level in hemolymph, feeding, and survival behaviors after hunger and studied the role of octopamine on these pharmacological experiments. Their experiments confirmed that octopamine in honeybee performs similarly to noradrenalin and adrenalin in mammals in modulating an animal's counter-regulatory response. The study evaluates different types of octopamine and tyramine receptors that might be involved in energy homeostasis. Many neurons that mediate the release of octopamine belong to the class median dorsal unpaired neurons, and their electrical qualities in cockroaches have been widely investigated by Lapied et al. (2017). Scheiner et al. (2017) reported the role of the fat body in regulating gustatory sensitivity accomplished by tyramine signaling in many behavioral races of the honeybee. Their findings proposed that distinctive tyramine signaling in the fat body play an essential role in the adaptability of labor division by modulating gustatory responsiveness (Fig. 1).
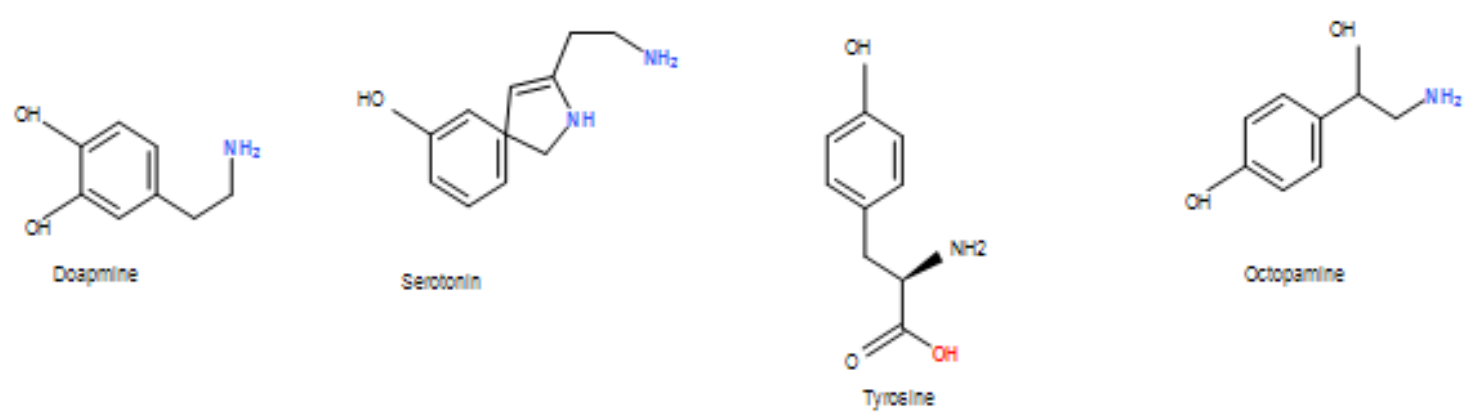

Figure 1. Chemical structure of each monoamine

Blenau et al. (2017) disclosed the fifth serotonin receptor in Drosophila melanogaster that is Dm5-HT2B. Besides that, three Dm5-HT7, Dm5-HT1B, and Dm5-HT1 along with the Dm5-HT2A and cyclic adenosine monophosphate (cAMP) signaling cascades directing toward $\mathrm{Ca} 2+$ signaling mechanism through ITP. Authors also reported that this important fifth receptor is concerned with immune system function and controlling heartbeat, and it can be aggravated by mianserin and metoclopramide. The circulation of immune reactivity for receptor molecules-AmTyr1 and tyramine has been reported by Sinakevitch et al. (2017) for the brain of the honeybee, and specific significance is positioned on neuropils related to olfactory sensation learning and memory (Fig. 2). They emphasized two important Ventral (Unpaired) median neurons of the suboesophageal ganglion belong to axons that arise to the bee's brain and stimulate the 
antennal lobe (AL) and mushroom body (MB) calyx. Remarkably, AmTyr1 expression was initiated in pre-synaptic positions of olfactory receptor neurons (ORN) and projection neurons, maximum prospective to apply for the inhibitory mechanism of neurotransmitter (Chemical messenger) release.

There is adding confirmation that octopamine and tyramine use opposite performances in insects. Their investigation upon Drosophila melanogaster (fruit fly) flight behavior, revealed the role and importance of tyramine and an enzymedehydrogenase/reductase for tyramine catabolism. This enzyme is found in the specific glial cells group, which is placed near the border of motor neuropil and through continuations toward the motor neuropil of flight. Whenever RNAi knocks down this enzyme, flight time is decreased, which is distinctive for high tyramine levels and blocked octopamine. This study also explores critical signaling pathways for tyramine (Ryglewski et al., 2017).

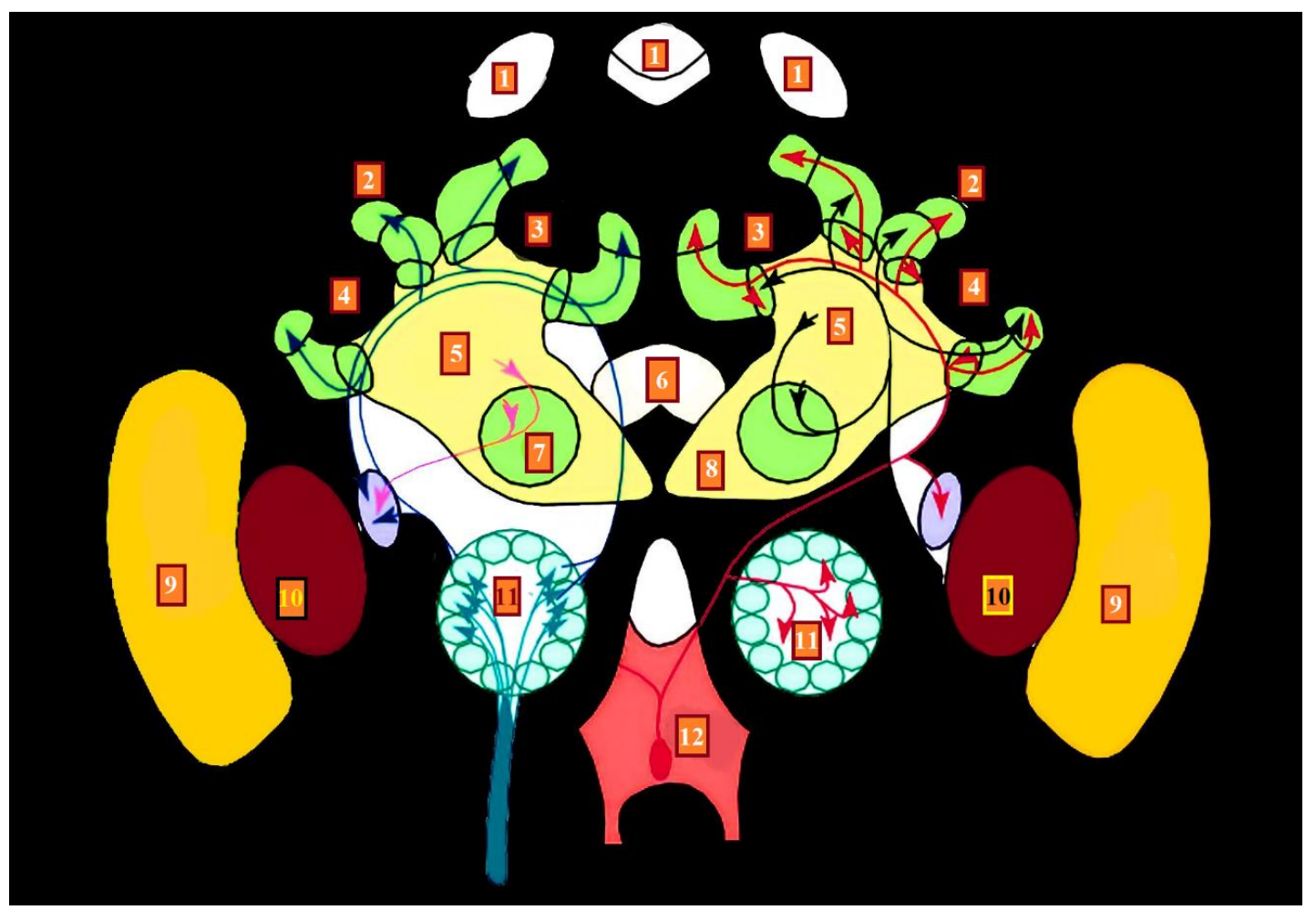

Figure 2. Schematic diagram of adult honeybee brain (frontal view). (1) Ocelli, (2) Mushroom bodies, (3) medial calyx, (4) lateral calyx, (5) peduncle, (6) central brain, (7) alpha lobe ( $\alpha$; vertical lobe), (8) beta lobe ( $\beta$ ); medial lobe), (9) medulla, (10) lobula, (11) antennal lobe, (12) suboesophageal ganglion., projection neurons (blue), VUMmxI (red), an inhibitory feedback loop (black), indirect input from the mushroom body to lateral protocerebrum (also called lateral horn, violet). (Source: Grünewald, 1999; Barron et al., 2015)

\section{Role of dopamine and dopamine receptors}

Berke (2018) described that dopamine transfer's motivational significance and encourages movement activity even at seconds time scales. They also reported that, is dopamine a signal for motivation or signal for learning, or both? Our knowledge about dopamine has modulated in the previous and is fluctuating once again. One essential and distinctive is between dopamine effects on future learning behavior and current 
performance behavior. Both kinds of behavior are significant and real, but sometimes one was in favor, and other was not. DA is a critical vital learning and motivation modulator. Dopamine receptors (D1-like, D2-like) are classified into two significant subfamilies. Dopamine is a major neurotransmitter that facilitates physiological tasks in both the peripheral and central nervous system (CNS) via relating to DA cell surface receptors. Dopamine receptors (D1-like, D2-like) are classified into two significant subfamilies. Dopamine is a major neurotransmitter that facilitates physiological tasks in both the peripheral and central nervous system (CNS) via relating to DA cell surface receptors. DA receptors are G-protein coupled receptors (GPCRS) that are categorized into (D1-like, D2-like) receptors based on their physiological, pharmacological, and biochemical effects (Fig. 3).

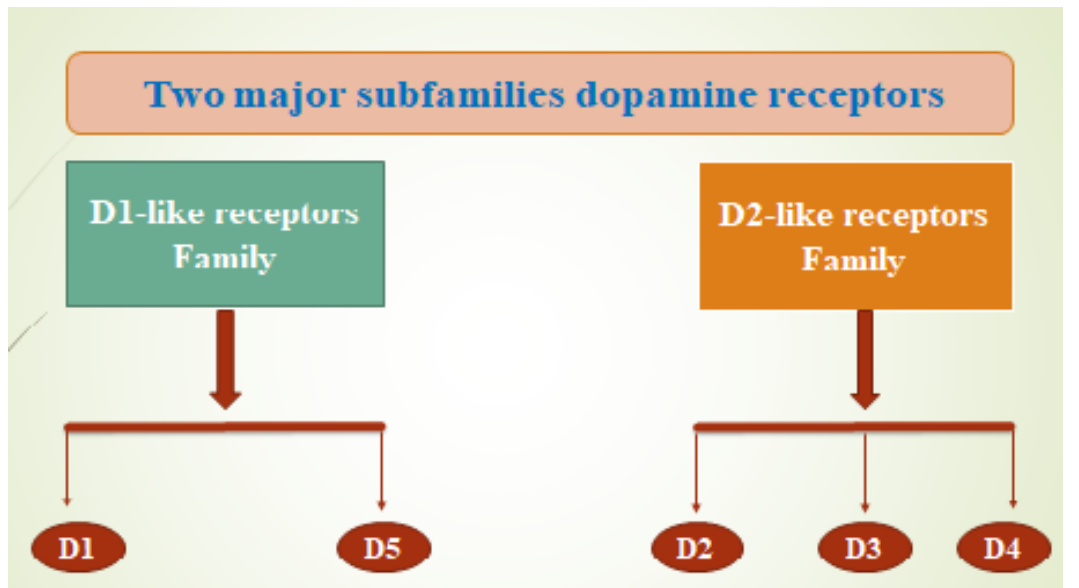

Figure 3. Dopamine receptors are divided in to two major subfamilies: D1-like and D2-like

\section{Physiology of dopamine receptors}

The biogenic amines (BA) of serotonin, dopamine, tyramine, and octopamine in the honeybee modify neuronal tasks in numerous ways. Serotonin and dopamine are present in the bee brain at high concentrations. Additionally, tyramine and octopamine are a small quantity. Octopamine is a critical molecule to regulate the behavior of honeybee. It usually has a stimulating effect and results in increasing the sensitivity of sensory inputs, improve learning efficacy, and better foraging behavior. Tyramine has been recommended to act as an inhibitor to octopamine, but only limited experimental data are available for this amine. Serotonin and Dopamine often have inhibitory effects in comparison with octopamine. Scheiner et al. (2006) reported the role of BA and biogenic amines receptor-mediated cellular responses regulating distinct behavior involved in learning performance and labor division. Biogenic amines (BA) bind to membrane receptors that belong primarily to big GTP-binding $(G)$ protein gene family combined with receptors. The behavioral function, the regional brain expression, selective antagonists, selective agonists, and mechanism of action of various types of dopamine receptors are outlined in (Table 1; Mishra et al., 2018).

Significant differences are produced in the concentration of Inositol trisphosphate receptor (IP3), (cAMP), and $\mathrm{Ca} 2+$ in intracellular Second messenger levels. Besides, several honeybee (BA) receptors have been characterized and cloned recently; still, several genes remained to be recognized. The approachability of the fully sequenced Apis mellifera genome will make a significant contribution in bridging this gap in Table 2. 
Table 1. Perspective and knowledge of different dopamine receptors

\begin{tabular}{|c|c|c|c|c|c|c|}
\hline Receptors & Location & Type & Mechanism & Function & $\begin{array}{c}\text { Selective } \\
\text { agonist }\end{array}$ & \begin{tabular}{|c|}
$\begin{array}{c}\text { Selective } \\
\text { antagonist }\end{array}$ \\
\end{tabular} \\
\hline D1 & \begin{tabular}{|c|} 
Olfactory bulb \\
Nucleus accumbens \\
Striatum \\
Amygdala \\
Hippocampus \\
Frontal cortex \\
Substantia nigra \\
Hypothalamus \\
\end{tabular} & Gs-coupled & $\begin{array}{c}\text { Enhanced intracellular } \\
\text { cAMP through } \\
\text { activated adenylate } \\
\text { cyclase }\end{array}$ & \begin{tabular}{|c|} 
Attention \\
Learning \\
Locomotion \\
Sleep \\
Impulse control \\
Regulation of renal function \\
Memory
\end{tabular} & $\begin{array}{l}\text { SKF-81297 } \\
\text { SKF-38393 } \\
\text { Fenoldopa } \\
\text { (SKF-82526) }\end{array}$ & $\begin{array}{l}\text { SCH-39166 } \\
\text { SKF-83566 } \\
\text { SCH-23390 }\end{array}$ \\
\hline D5 & $\begin{array}{l}\text { Hypothalamus } \\
\text { Substantia nigra } \\
\text { Cortex }\end{array}$ & Gs-coupled & Adenylate cyclase & $\begin{array}{l}\text { Motor } \\
\text { Learning } \\
\text { Cognition } \\
\text { Decision } \\
\text { Making } \\
\text { Renin } \\
\text { Secretion } \\
\end{array}$ & & \\
\hline D2 & $\begin{array}{c}\text { VTA } \\
\text { Olfactory bulb } \\
\text { Striatum } \\
\text { Cerebral cortex }\end{array}$ & Gi-coupled & $\begin{array}{c}\text { Increased level of } \\
\text { cAMP intracellular by } \\
\text { activating adenylate } \\
\text { cyclase }\end{array}$ & $\begin{array}{l}\text { Reproductive behavior } \\
\text { Locomotion } \\
\text { Sleep } \\
\text { Attention }\end{array}$ & $\begin{array}{l}\text { Bromocriptine } \\
\text { Pergolide } \\
\text { Cabergoline } \\
\text { Ropinirole }\end{array}$ & \begin{tabular}{|c} 
Haloperidol \\
Raclopride \\
Sulpiride \\
Spiperone \\
Risperidone \\
\end{tabular} \\
\hline D3 & $\begin{array}{c}\text { Cortex } \\
\text { Islands of Calleja } \\
\text { Striatum }\end{array}$ & Gi-coupled & & $\begin{array}{l}\text { Locomotion } \\
\text { Regulation of food intake } \\
\text { Impulse control } \\
\text { Cognition }\end{array}$ & \begin{tabular}{|c} 
Nafadotride GR- \\
103691 GR- \\
218231 SB- \\
277011A NGB- \\
2904 PG-01037 \\
ABT-127
\end{tabular} & $\begin{array}{c}\text { 7-OH- } \\
\text { DPAT } \\
\text { Pramipexole } \\
\text { Rotigotine } \\
\text { PD-128907 }\end{array}$ \\
\hline D4 & \begin{tabular}{|c|} 
Hypothalamus \\
Amygdala \\
Frontal cortex \\
Nucleus accumbens
\end{tabular} & 1- Gi-coupled & & $\begin{array}{c}\text { Attention } \\
\text { Impulse control } \\
\text { Reproductive behavior }\end{array}$ & $\begin{array}{l}\text { A-381393 } \\
\text { FAUC213L- } \\
745870 \mathrm{~L}- \\
750667\end{array}$ & $\begin{array}{l}\text { A-412997 } \\
\text { ABT-670 } \\
\text { PD-168077 }\end{array}$ \\
\hline
\end{tabular}

Table 2. The role of dopamine receptors genes of vertebrate and invertebrate

\begin{tabular}{|c|c|c|c|c|}
\hline Gene ID & Gene name & Organisms & Function & References \\
\hline 1621 & $\begin{array}{c}\text { Dopamine beta- } \\
\text { hydroxylase }\end{array}$ & Homo sapiens & $\begin{array}{c}\text { Plays a dominant role in the process of } \\
\text { converting dopamine into norepinephrine (NE) }\end{array}$ & Tang et al., 2018 \\
\hline 37867 & $\begin{array}{c}\text { Dopamine } \mathrm{N} \\
\text { acetyltransferase }\end{array}$ & $\begin{array}{c}\text { Drosophila } \\
\text { melanogaster }\end{array}$ & $\begin{array}{c}\text { Encodes an enzyme that is identified to show a } \\
\text { part in the insect pigmentation pathway }\end{array}$ & $\begin{array}{l}\text { Ahmed-Braimah and } \\
\text { Sweigart, } 2015\end{array}$ \\
\hline 406111 & $\begin{array}{l}\text { Dopamine receptor, } \\
\text { D1 }\end{array}$ & Apis mellifera & $\begin{array}{l}\text { Regulating behavioral plasticity in the honey } \\
\text { bee }\end{array}$ & $\begin{array}{l}\text { McQuillan et al., } 2012 \text { a; } \\
\text { Elsik et al., } 2014\end{array}$ \\
\hline 408995 & $\begin{array}{l}\text { D2-like dopamine } \\
\text { receptor }\end{array}$ & Apis mellifera & $\begin{array}{l}\text { Cognition, impulse, locomotion, control, } \\
\text { attention }\end{array}$ & Mishra et al., 2018 \\
\hline 41726 & $\begin{array}{l}\text { Dopamine } 1 \text {-like } \\
\text { receptor } 1\end{array}$ & $\begin{array}{l}\text { Drosophila } \\
\text { melanogaster }\end{array}$ & $\begin{array}{c}\text { Memory formation for aversive and appetitive } \\
\text { learning }\end{array}$ & Swenson et al., 2016 \\
\hline 25432 & $\begin{array}{l}\text { Dopamine receptor } \\
\text { D4 }\end{array}$ & Rattus norvegicus & Modulates fear expression & Vergara et al., 2017 \\
\hline 43484 & $\begin{array}{l}\text { Dopamine } 1 \text {-like } \\
\text { receptor } 2\end{array}$ & $\begin{array}{c}\text { Drosophila } \\
\text { melanogaster }\end{array}$ & $\begin{array}{c}\text { For initiating biochemical cascades underlying } \\
\text { olfactory learning. }\end{array}$ & Swenson et al., 2016 \\
\hline 1816 & $\begin{array}{l}\text { Dopamine receptor } \\
\text { D5 }\end{array}$ & Homo sapiens & Tumor and cancer treatment & Leng et al., 2017 \\
\hline 13491 & $\begin{array}{l}\text { Dopamine receptor } \\
\text { D4, Drd4 }\end{array}$ & Mus musculus & $\begin{array}{c}\text { Social interaction, novelty-seeking, increased } \\
\text { anxiolytic and exploratory behavior, alcohol } \\
\text { binge }\end{array}$ & Thanos et al., 2015 \\
\hline
\end{tabular}

\section{Types of dopamine receptors}

Dopamine receptors are five distinct kinds (D1, D2, D3, D4, and D5), all receptors, coupled with G-proteins. These subtypes are categorized into two significant classes 
(D1 like receptors and D2 like receptors). D1 like receptors are excitatory and postsynaptic. D2 like receptors are inhibitory, pre-synaptic, and post-synaptic. (Rang HP, 2006) summarized the overview of activation of each receptor type, follow the comparison of kinds and function of dopamine receptors, and Under comparison of the kinds and tasks of dopamine receptors, it is possible to determine how the dopaminergic system unique built-in phyla. Ferreri et al. (2019) demonstrated that dopamine role is related to the pleasure of music experience. They orally controlled each contributor, a dopamine antagonist (risperidone), a placebo (lactose), and a dopamine precursor (levodopa) in three separate sessions, according to their results, risperidone and levodopa led to a conflicting response in trials of motivation and musical pleasure. Although the placebo compared with dopamine precursor levodopa, improved the cognitive experience and motivational responses associated with music, but risperidone result decreased in both. Shows a vital function musical pleasure of dopamine and specifies that dopaminergic transmission could play a distinct role.

In recent studies,(Beggs and Mercer (2009) found that Queen mandibular pheromone produced by the queen is used to control the physiology and behaviors of their colony individual. Homovanillyl alcohol is one of the significant components of Queen mandibular pheromone QMP in blocking aversive learning in young working bees. Homovanillyl alcohol (HVA) was found to reduce the concentration of brain dopamine and modify the intracellular cAMP concentration in the centers of the brain concerned with learning and memory. They investigated that HVA directly interacts with the bee's dopamine receptor, also HVA activates AmDOP3 (D2-like dopamine receptor) selectively. They suggested a specific molecular system through which dopamine signaling pathways can be modulated. Apis mellifera dopamine receptor (DOP3) induced blockage of aversive learning in worker bees is caused by HVA (Beggs and Mercer, 2009).

In a study on Apis mellifera brain, Lerner et al. (1995) observed that expression of amino-receptors varies significantly throughout Kenyon cell subpopulations. In present models of mushroom body function, differential expression of amine-receptor genes in neurons and plasticity that exists at this stage are mainly ignored characteristics. Their findings are consistent with confirmation that short- term and long-term sensory memories formed in distinct parts of the brain's mushroom bodies and there are efficient parts of the brain center (McQuillan et al., 2012 b). They illustrated the role of gene expression in reproductive organisms of male honeybee are throughout the sexual development and maturation. Dopamine is a distinct operator between three reproductive systems and CNS. They also suggested that in seminal vesical of honeybee brain, 20 dopamine receptors can be used to drive dopamine (DA) for reproduction and 21 receptors involved in storage and sperm transfer in the reproductive organ of males (Matsushima et al., 2019).

In these studies, they investigated specific caste development of the dopaminergic system in female honeybees during metamorphosis. Caste-specific changes by dopaminergic systems in social insects help to continue caste-specific behavior. Their findings showed that the developmental procedure of caste-specific dopaminergic systems in honey bee during metamorphosis recommends caste-specific behavior and reproduction division in this greatly eusocial species (Sasaki et al., 2018).

Mustard et al. (2010) investigated that dopamine and D1-like receptors (AmDOP2) cause regulation of motor behavior in the honeybee. Assessing the particular molecular pathways by which dopamine impacts behavior complexed by the involvement of 
various subtypes of dopamine receptors linking distinct second messenger pathways. Spontaneous movements of adult bees in the field were used to explore the role of dopamine signaling in modulating the behavior of honeybee. A significant difference between control and treated bees was observed for many behaviors such as flying, grooming, fanning, stopped walking and upside down. Finally, their findings established that DA plays a significant role in modulating the motor behavior of the Apis mellifera (Mustard et al., 2010).

Kokay and Mercer (1997) found the developmental changes in densities of dopamine receptors and the measurement of dopamine levels in the honeybee brain. Their findings confirmed the expression of dopamine receptor subtype-specific patterns in insect brain and illustrated that D1 and D2-like receptors are not only expressed in the adult bees CNS, as well as during bee's brain developmental stages (Fig. 4)

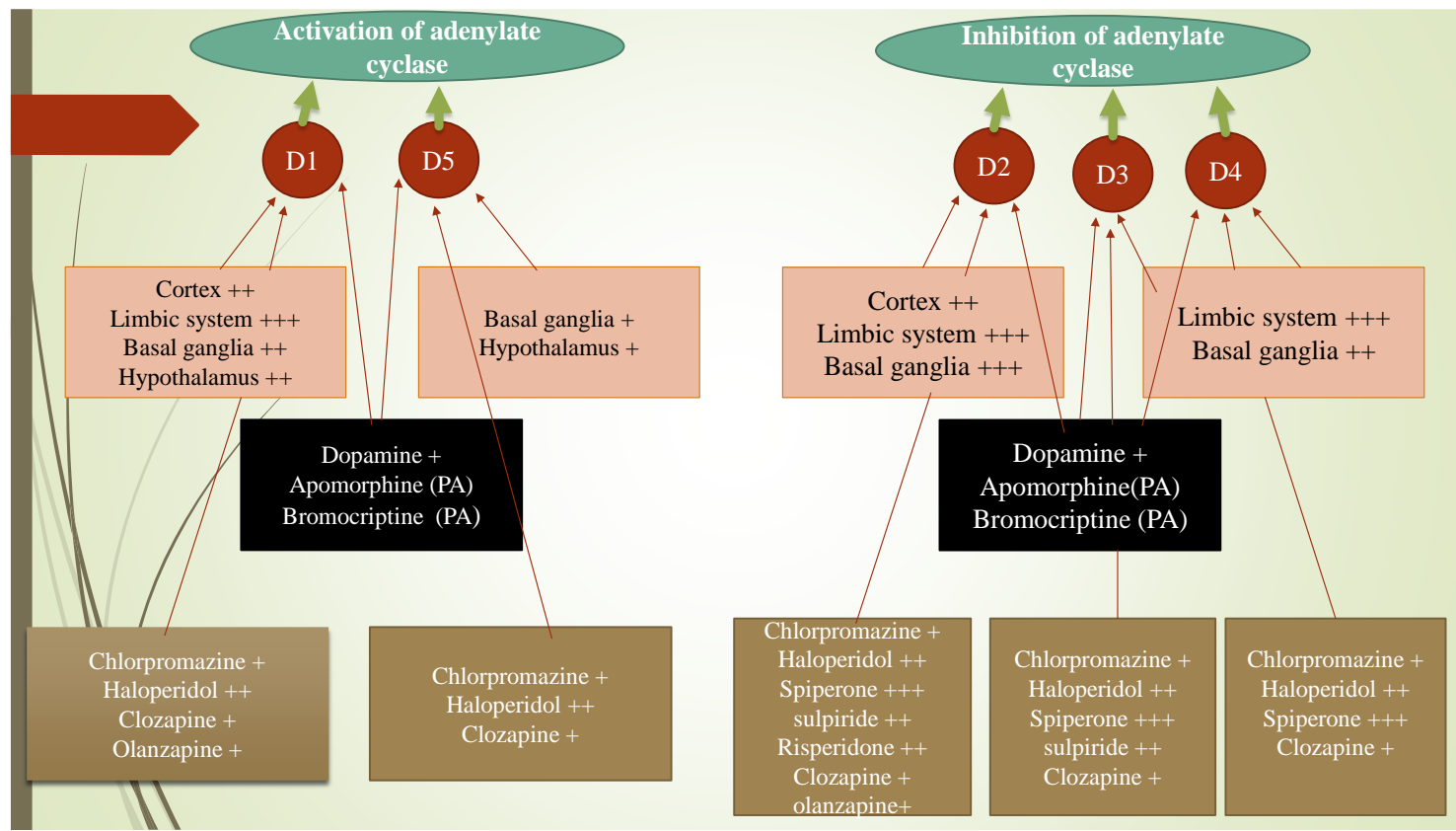

Figure 4. Expression of dopamine receptor

\section{Role of dopamine in insects}

Locusta migratoria (migratory locust), showed incredible phenotypic adaptability in response to the population density variation at morphological, physiological, and cognitive levels. In migratory locust, two dopamine (Dop1 and Dop2) receptors play distinct roles in developmental changes. DA and dopamine genes in metabolic pathways facilitate phase modification in L. migratoria. They proved that dopamine (Dop1 and Dop2) controlled locust phase variation in two various directions (Guo et al., 2015).

The significant role of dopamine being strengthening and processing is applied in a range of species varying from Homo sapiens to Drosophila melanogaster, while D1 receptors have been recognized to make a significant contribution to fruit flies' aversive odor sensitivity learning. Scholz-Kornehl and Schwartzel (2016) revealed that D2 receptors endorsed to facilitate a combined type of odor memory referred to as anesthesia-resistant learning and memory. Observing the distinct role of dopamine and dopamine receptor (D2R) in "forgetting"(retroactive role of dopamine), balancing, 
acquisition of memory (the proactive task of dopamine) and dopamine release, their findings recommended D2R as the crucial player of each process (Scholz-Kornehl and Schwärzel, 2016). Ichinose et al. (2017) analyzed the function of dopaminergic neurons in the fruit fly brain, and how they influence the animal's internal condition/cognitive behavior. Dopamine might play both roles, a slow neuromodulator, a fast neurotransmitter. It depends on the postsynaptic neuron. Genetic modification of dopamine neuron activity resulted in differences in the fly's behavior. Behaviors such as learning and memory, sexual drive, sleep, and hunger were affected (Ichinose et al., 2017).

Zhukovskaya and Polyanovsky (2017) studied the effects of various amines such as octopamine, tyramine, dopamine, and serotonin on olfactory and gustatory receptor neurons in insect antennae. Many amines systemically released into the hemolymph, an open circulatory system in insects, supplied different body compartments, the dorsal or ventral cavity, the muscles, the central nervous system, and so on.. The authors suggest that the antenna may be a partially autonomous hemolymph compartment separated from other body parts. An important aspect of chemical signaling is that all transmitters, whether they be classical transmitters, neuromodulators, or hormones, can only act through their respective receptor molecules. Depending on which receptor type activated, different signaling cascades can be triggered. In this issue, some articles devoted to receptors. Niens et al. (2017) showed that in the fruit fly, imbalances between dopamine and serotonin are modeled. Like in rodents, a lack of dopamine leads to increased levels of 5-HT and arborizations in specific brain neuropils.

Conversely, increased dopamine levels lead to reduced connectivity of 5-HT neurons., both neurons, dopamine, and 5-HT play an essential role in learning behavior. Dopamine signaling is critical for mediating reinforcing properties of unconditioned stimuli during associative learning. Tedjakumala et al. (2017) characterized dopaminergic neurons in the honeybee brain by immune reactivity distribution of dopamine precursor enzyme, tyrosine-hydroxylase. They also describe new clusters of dopaminergic neurons. Sun et al. (2018) studied startle-induced locomotion and the activity of specific clusters of dopaminergic neurons afferent to the mushroom bodies.

\section{Conclusion}

Receptors of dopamine (DA) have a crucial role in a broad range of behavior, such as motor function, sensory processing, arousal, and reward. In this way, abnormal dopamine signaling is correlated with many psychiatric and neurological disorders. Comprehension of the pathways through which DA neurotransmission motivates intracellular signaling mechanisms, that behavior modulation can provide essential insights for the development of specific therapeutics. Since these general themes begin to emerge, a lot of work needs to be done to distinguish the particular signaling mechanisms of DA receptors in simple model organisms.

This mini review also contributes toward an emerging picture of the brain circuits modulating locomotor reactivity that appear to both overlaps and differ from those mediating associative learning and memory, sleep/wake state, and stress-induced hyperactivity. Furthers, requires more investigation on the molecular, pharmacological, functional, and physiological basis of dopamine receptors and functions in modulating phase change will improve our understanding of the molecular mechanism underlying phenotypic plasticity in honeybee and model insects. 


\section{REFERENCES}

[1] Ahmed-Braimah, Y. H., Sweigart, A. L. (2015): A single gene causes an interspecific difference in pigmentation in Drosophila. - Genetics 200(1): 331-342.

[2] Barron, A. B., Gurney, K. N., Meah, L. F., Vasilaki, E., Marshall, J. A. (2015): Decisionmaking and action selection in insects: inspiration from vertebrate-based theories. Frontiers in Behavioral Neuroscience 9: 216.

[3] Beggs, K. T., Mercer, A. R. (2009): Dopamine receptor activation by honey bee queen pheromone. - Current Biology 19(14): 1206-1209.

[4] Berke, J. D. (2018): What does dopamine mean? - Nature neuroscience 21(6): 787-793.

[5] Blenau, W., Daniel, S., Balfanz, S., Thamm, M., Baumann, A. (2017): Dm5-ht2b: pharmacological characterization of the fifth serotonin receptor subtype of drosophila melanogaster. - Frontiers in Systems Neuroscience 11: 28.

[6] Buckemüller, C., Siehler, O., Göbel, J., Zeumer, R., Ölschläger, A., Eisenhardt, D. (2017): Octopamine underlies the counter-regulatory response to a glucose deficit in honeybees (Apis mellifera). - Frontiers in Systems Neuroscience 11: 63.

[7] Damrau, C., Toshima, N., Tanimura, T., Brembs, B., Colomb, J. (2018): Octopamine and tyramine contribute separately to the counter-regulatory response to sugar deficit in Drosophila. - Frontiers in Systems Neuroscience 11: 100.

[8] Elsik, C. G., Worley, K. C., Bennett, A. K., Beye, M., Camara, F., Childers, C. P., de Graaf, D. C., Debyser, G., Deng, J., Devreese, B., Elhaik, E. (2014): Finding the missing honey bee genes: lessons learned from a genome upgrade. - BMC Genomics 15(1): 86.

[9] Ferreri, L., Mas-Herrero, E., Zatorre, R. J., Ripollés, P., Gomez-Andres, A., Alicart, H., Olivé, G., Marco-Pallarés, J., Antonijoan, R. M., Valle, M., Riba, J. (2019): Dopamine modulates the reward experiences elicited by music. - Proceedings of the National Academy of Sciences 116(9): 3793-3798.

[10] Grünewald, B. (1999): Morphology of feedback neurons in the mushroom body of the honeybee, Apis mellifera. - Journal of Comparative Neurology 404(1): 114-126.

[11] Guo, X., Ma, Z., Kang, L. (2015): Two dopamine receptors play different roles in phase change of the migratory locust. - Frontiers in Behavioral Neuroscience 9: 80.

[12] Ichinose, T., Tanimoto, H., Yamagata, N. (2017): Behavioral modulation by spontaneous activity of dopamine neurons. - Frontiers in Systems Neuroscience 11: 88.

[13] Kamhi, J. F., Arganda, S., Moreau, C. S., Traniello, J. F. (2017): Origins of aminergic regulation of behavior in complex insect social systems. - Frontiers in Systems Neuroscience 11: 74.

[14] Kokay, I. C., Mercer, A. R. (1997): Age-related changes in dopamine receptor densities in the brain of the honey bee, Apis mellifera. - Journal of Comparative Physiology A 181(4): 415-423.

[15] Lapied, B., Defaix, A., Stankiewicz, M., Moreau, E., Raymond, V. (2017): Modulation of low-voltage-activated inward current permeable to sodium and calcium by DARPP-32 drives spontaneous firing of insect octopaminergic neurosecretory cells. - Frontiers in Systems Neuroscience 11: 31 .

[16] Leng, Z. G., Lin, S. J., Wu, Z. R., Guo, Y. H., Cai, L., Shang, H. B., Tang, H., Xue, Y. J., Lou, M. Q., Zhao, W., Le, W. D. (2017): Activation of DRD5 (dopamine receptor D5) inhibits tumor growth by autophagic cell death. - Autophagy 13(8): 1404-1419.

[17] Lerner, T. J., Boustany, R. M. N., Anderson, J. W., D’Arigo, K. L., Schlumpf, K., Buckler, A. J., Gusella, J. F., Haines, J. L. (1995): Isolation of a novel gene underlying Batten disease, CLN3. - Cell 82(6): 949-957.

[18] Li, Y., Tiedemann, L., von Frieling, J., Nolte, S., El-Kholy, S., Stephano, F., Gelhaus, C., Bruchhaus, I., Fink, C., Roeder, T. (2017): The role of monoaminergic neurotransmission for metabolic control in the fruit fly Drosophila melanogaster. - Frontiers in Systems Neuroscience 11: 60 . 
[19] Matsushima, K., Watanabe, T., Sasaki, K. (2019): Functional gene expression of dopamine receptors in the male reproductive organ during sexual maturation in the honey bee (Apis mellifera L.). - Journal of Insect Physiology 112: 9-14.

[20] McQuillan, H. J., Barron, A. B., Mercer, A. R. (2012a): Age-and behaviour-related changes in the expression of biogenic amine receptor genes in the antennae of honey bees (Apis mellifera). - Journal of Comparative Physiology A 198(10): 753-761.

[21] McQuillan, H. J., Nakagawa, S., Mercer, A. R. (2012b): Mushroom bodies of the honeybee brain show cell population-specific plasticity in expression of amine-receptor genes. - Learning \& Memory 19(4): 151-158.

[22] Mishra, A., Singh, S., Shukla, S. (2018): Physiological and functional basis of dopamine receptors and their role in neurogenesis: possible implication for Parkinson's disease. Journal of Experimental Neuroscience 12: 1179069518779829.

[23] Mustard, J. A., Pham, P. M., Smith, B. H. (2010): Modulation of motor behavior by dopamine and the D1-like dopamine receptor AmDOP2 in the honey bee. - Journal of Insect Physiology 56(4): 422-430.

[24] Niens, J., Reh, F., Çoban, B., Cichewicz, K., Eckardt, J., Liu, Y. T., Hirsh, J., Riemensperger, T. D. (2017): Dopamine modulates serotonin innervation in the drosophila brain. - Frontiers in Systems Neuroscience 11: 76.

[25] Rang, H. P., Dale, M. M., Ritter, J. M., Moore, P. K. (2006): Pharmacology 5th Ed. Churchill Livingstone, London.

[26] Ryglewski, S., Duch, C., Altenhein, B. (2017): Tyramine actions on Drosophila flight behavior are affected by a glial dehydrogenase/reductase. - Frontiers in Systems Neuroscience 11: 68.

[27] Sasaki, K., Ugajin, A., Harano, K. I. (2018): Caste-specific development of the dopaminergic system during metamorphosis in female honey bees. - PloS One 13(10).

[28] Scheiner, R., Baumann, A., Blenau, W. (2006): Aminergic control and modulation of honeybee behaviour. - Current Neuropharmacology 4(4): 259-276.

[29] Scheiner, R., Entler, B. V., Barron, A. B., Scholl, C., Thamm, M. (2017): The effects of fat body tyramine level on gustatory responsiveness of honeybees (Apis mellifera) differ between behavioral castes. - Frontiers in Systems Neuroscience 11: 55.

[30] Scholz-Kornehl, S., Schwärzel, M. (2016): Circuit analysis of a Drosophila dopamine type 2 receptor that supports anesthesia-resistant memory. - Journal of Neuroscience 36(30): 7936-7945.

[31] Sinakevitch, I. T., Daskalova, S. M., Smith, B. H. (2017): The biogenic amine tyramine and its receptor (AmTyr1) in olfactory neuropils in the honey bee (Apis mellifera) brain. - Frontiers in Systems Neuroscience 11: 77.

[32] Stocker, B., Bochow, C., Damrau, C., Mathejczyk, T., Wolfenberg, H., Colomb, J., Weber, C., Ramesh, N., Duch, C., Biserova, N. M., Sigrist, S. (2018): Structural and molecular properties of insect type II motor axon terminals. - Frontiers in Systems Neuroscience 12: 5.

[33] Sun, J., Xu, A. Q., Giraud, J., Poppinga, H., Riemensperger, T., Fiala, A., Birman, S. (2018): Neural control of startle-induced locomotion by the mushroom bodies and associated neurons in Drosophila. - Frontiers in Systems Neuroscience 12: 6.

[34] Swenson, J. M., Colmenares, S. U., Strom, A. R., Costes, S. V., Karpen, G. H. (2016): The composition and organization of Drosophila heterochromatin are heterogeneous and dynamic. - Elife 5: e16096.

[35] Tang, S., Yao, B., Li, N., Lin, S., Huang, Z. (2018): Association of dopamine betahydroxylase polymorphisms with Alzheimer's disease, Parkinson's disease and schizophrenia: evidence based on currently available loci. - Cellular Physiology and Biochemistry 51(1): 411-428.

[36] Tedjakumala, S. R., Rouquette, J., Boizeau, M. L., Mesce, K. A., Hotier, L., Massou, I., Giurfa, M. (2017): A tyrosine-hydroxylase characterization of dopaminergic neurons in the honey bee brain. - Frontiers in Systems Neuroscience 11: 47. 
[37] Thanos, P. K., Roushdy, K., Sarwar, Z., Rice, O., Ashby Jr, C. R., Grandy, D. K. (2015): The effect of dopamine D 4 receptor density on novelty seeking, activity, social interaction, and alcohol binge drinking in adult mice. - Synapse 69(7): 356-364.

[38] Vergara, M. D., Keller, V. N., Fuentealba, J. A., Gysling, K. (2017): Activation of type 4 dopaminergic receptors in the prelimbic area of medial prefrontal cortex is necessary for the expression of innate fear behavior. - Behavioural Brain Research 324: 130-137.

[39] Zhukovskaya, M. I., Polyanovsky, A. D. (2017): Biogenic amines in insect antennae. Frontiers in Systems Neuroscience 11: 45. 